\title{
ANALISIS FAKTOR-FAKTOR YANG MEMENGARUHI PENANGANAN PADA ANAK AUTIS DI SLB ANEUK NANGGROE DAN CINTA MANDIRI KOTA LHOKSEMAWE PROVINSI ACEH
}

\author{
Mailindawati $^{1}$, Khairul Azwar ${ }^{2}$, Eka Sutrisna ${ }^{3}$ \\ STIKes Getsempena Lhoksukon \\ mailindawati888@gmail.com¹, khairulazwar430@gmail.com²
}

\begin{abstract}
Autism is a collection of developmental disorders characterized by difficulty interacting socially, Autism has an impact on children as well as on families. The impact on children is poor school achievement, low work status, health problems suffered, psychosocial impacts (needs for comfort, needs to be loved and loved, needs for self-esteem, self-actualization and impaired social interaction) and increased risk of accidents. Handling autistic children must be holistic, such as diet therapy, occupational therapy, speech therapy and biomedicine, if done incompletely and separately the results are not optimal. The purpose of the study was to analyze the factors that influence the treatment of autistic children. Type of observational analytic research with cross-sectional study design. The research sample with a population of 31 people in Aneuk Nanggroe and Cinta Mandiri Special Schools, Lhoksemawe City, Aceh Province. The instrument in this study was made in the form of a questionnaire. Data were analyzed using linear regression and chi square for bivariate. Results of research conducted from April to August 2021. The results showed that there was a relationship between parenting and handling of autistic children ( $p$ value 0.04) or $p<0.05$, there is no relationship between diet and treatment of autistic children ( $p$ value 0.06) or $p>0.05$ and there is a relationship between social stories therapy and the treatment of autistic children ( $p$ value 0.04) or $p>0.05$. Suggestions to the community are expected to provide information about parenting and eating patterns in autistic children, and as motivation for parents who have autistic children.
\end{abstract}

Keywords

: Dietary habit; Parenting; Autism Treatment; Social Stories Therapy.

\begin{abstract}
ABSTRAK
Autisme merupakan kumpulan kondisi kelainan perkembangan yang ditandai dengan kesulitan berinteraksi sosial. Autisme membawa dampak pada anak dan juga pada keluarga. Dampak pada anak adalah prestasi sekolah yang buruk, status pekerjaan yang rendah, gangguan kesehatan yang diderita, dampak psikososial (kebutuhan rasa nyaman, kebutuhan dicintai dan mencintai, kebutuhan harga diri, aktualisasi diri dan gangguan interaksi social) serta risiko kecelakaan meningkat. Penanganan anak autis harus secara holistik, seperti terapi diet, terapi okupasi, terapi bicara dan biomedis, bila dilakukan tidak lengkap dan terpisah hasilnya tidak optimal. Tujuan penelitian untuk menganalisis Faktor-Faktor yang Memengaruhi Penanganan Pada Anak Autis. Jenis penelitian analitik observasional dengan desain study crossectional. Sampel penelitian dengan jumlah populasi 31 orang yang ada di SLB Aneuk Nanggroe dan Cinta Mandiri kota Lhoksemawe Provinsi Aceh. Instrumen dalam Penelitian ini dibuat dalam bentuk Kuesioner. Data dianalisis menggunakan regresi linier dan chi square untuk bivariat. Hasil penelitian yang dilaksanakan dari bulan April sampai Agustus 2021. Hasil penelitian menunjukkan adanya hubungan pola asuh dengan penanganan anak autis $(p$ value 0.04 ) atau $\mathrm{p}<0,05$, tidak adanya hubungan pola makan dengan penanganan anak autis ( $\mathrm{p}$ value 0.06 ) atau $p>0,05$ dan adanya hubungan terapi social stories dengan penanganan anak autis ( $p$ value 0.04 ) atau $p>0,05$. Saran kepada masyarakat diharapkan dapat meberikan informasi tentang pola asuh dan pola makan pada anak autis, dan sebagai motivasi bagi orang tua yang memiliki anak autis.
\end{abstract}

Kata Kunci $\quad$ : Pola Makan; Penanganan Autis; Pola Asuh; Terapi Social Stories 


\section{PENDAHULUAN}

Autis asal kata "autos" yang artinya segala sesuatu yang mengarah pada diri sendiri. Autis merupakan preokupasi untuk pikiran serta khayalan diri sendiri atau lebih banyaknya orientasi kepada pikiran yang bersifat subyektif sendiri daripada untuk melihat kenyataan atau realita pada kehidupan sehari-hari (Budiyanto, 2018). Data World Health Organization (WHO) tahun 2013 diperkirakan 1 dari 160 anak memiliki autis. Sedangkan di Indonesia peningkatan pada anak terus mengalami peningkatan, karena pemerintah belum pernah melakukan survey terhadap anak autis (Fatmawati, 2014).

Keluarga merupakan orang utama yang seharusnya mendukung perkembangan anak autis, walaupun seringkali kelahiran serta keberadaan anak autis menimbulkan masalah pada keluarga. Tahap tidak dapat menerima, shock, kecewa, pengabaian, ketidakpercayaan, dan rasa jengkel dan marah seringkali dialami orangtua pada anak autis. Keadaan tidak dapat menerima kondisi anak autis membuat pola asuh pada anak autis akibatnya tidak maksimal. Bahkan seringkali menjadi masalah emosional pada keluarga. Perhatian dari orang tua diperlukan pada anak autis terutama ibu terlibat dalam mengasuh anak autis sepanjang hari (Mohammadi, 2014). Orang tua dapat memberikan pola asuh yang baik terhadap anak autis dengan membuat jadwal rutin harian anak yaitu pemangkasan waktu yang berhubungan dengan dunia elektronik (Gunadi, 2011).

Penanganan pada anak autis dilakukan secara menyeluruh, yaitu terapi diet, terapi bicara, terapi okupas dan biomedis, bila pelaksanaanya tidak lengkap serta terpisah tentunya hasilnya tidak akan optimal. Beberapa penelitian dalam bidang nutrisi, imunologi, gastroenterologi, dan endokrinologi menunjukkan dengan adanya terapi diet atau makanan dapat memperbaiki gangguan pada saluran pencernaan, sebagai penyebab fungsi otak pada anak autis, keadaan ini dapat menjelaskan bahwasannya pendekatan diet dapat meminimalkan gangguan perilaku autis (Lyte \& Cryan, 2014).

Hubungan pola makan terhadap penanganan anak autis merupakan pola makan yang harus diterapkan adalah pola CFGF (Casein Free, Gluten Free) atau bebas casein dan gluten. Makanan yang mengandung casein adalah susu sapi dan olahannya. Adapun makanan yang mengandung gluten adalah makanan berbahan dasar terigu, seperti mie instan, roti, dan biskuit, serta makanan yang mengandung banyak gula, seperti permen, cokelat, dan es krim. Anak autis juga dilarang untuk mengonsumsi MSG dan buah yang mengandung zat phenol, yakni buah yang berubah warna setelah terkupas, misalnya apel dan pisang.Agar adanya perkembangan pesat dalam kemampuan bersosialisasi dan berkomunikasi setelah menjalani terapi (Gunadi, 2011).

Sekolah Luar Biasa (SLB) Anek Nanggroe dan Sekolah Luar Biasa (SLB) Cinta Mandiri Kota Lhoksemawe Provinsi Aceh, dihitung pada tahun 2019-2020 di SLB Aneuk Nanggroe terdapat 16 orang anak tingkat Sekolah Dasar yang mengalami autisme, dan SLB Cinta mandiri tahun 2019-2020 terdapat 15 anak tingkat Sekolah Dasar yang mengalami autis (Data SLB Aneuk Nanggroe Dan SLB Cinta Mandiri, 2020).

Berdasarkan survey awal yang diperoleh dari wawancara dengan guru SLB Aneuk Nanggroe, terdapat sebagian anak autis yang mendapatkan pola asuh yang baik dan ada pula yang kurang mendapatkan perhatian orangtua diakibatkan karena orang tua yang telah cerai atau broken home. Sebagian orang tua mengatakan syok pada saat pertama mengetahui anaknya mengalami gangguan autisme, tetapi tidak membuat mereka melantarkan atau tidak mempedulikan anaknya, mereka tetap mensuport anaknya dam meberikan pola asuh yang baik terhadap anaknya, akan tetapi sebagian orang tua terhambat dalam ekonomi nya untuk memenuhi kebutuhan anak autisme, 
sehingga kurang terkontrol terhadap pola makannya.

Tujuan penelitian adalah Faktor-Faktor yang Memengaruhi Penanganan Pada Anak Autis di SLB Aneuk Nanggroe dan Cinta Mandiri kota Lhoksemawe Provinsi Aceh.

\section{METODE}

Penelitian ini menggunakan pendekatan kualitatif. Variabel penelitian adalah pola asuh, pola makan dan terapi social stories terhadap penanganan anak autis. Peneliti melakukan penelitian di SLB Aneuk Nanggroe dan Cinta Mandiri kota Lhoksemawe Provinsi Aceh.. Waktu penelitian dilakukan dari bulan AprilOktober tahun 2021. Populasi dalam penelitian ini adalah seluruh orang tua dan anak autis di SLB Aneuk Nanggroe dan SLB Cinta Mandiri yang berjumlah 31 orang. Sampel yang diambil dalam penelitian ini adalah dengan menggunakan teknik purposive sampling yaitu mengambil sampel sesuai pertimbangan peneliti yang telah ditentukan pada krirteria inklusi.

Tekhnik pengumpulan data dengan penyebaran kuisioner dan pengamatan kepada pada anak autis. Analisa univariat dilakukan untuk mengetahui distribusi frekuensi dan persentase dalam bentuk tabel. Data kemudian dianalisis menggunakan regresi linier dan chi square untuk mengetahui ada hubungan atau tidak variable independen dan dependen.

\section{HASIL}

\section{Pengaruh Pola Asuh Terhadap Penanganan Anak Autis}

Dari hasil yang peneliti dapatkan mengenai Pengaruh Pola Asuh Terhadap Penanganan Anak Autis Di SLB Aneuk Nanggroe Dan Cinta Mandiri Kota Lhoksemawe Provinsi Aceh adalah sebagai berikut:

Tabel 1. Pengaruh Pola Asuh Terhadap Penanganan Anak Autis Di Sekolah Luar Biasa Aneuk Nanggroe Dan Cinta Mandiri Kota Lhoksemawe Provinsi Aceh

\begin{tabular}{|c|c|c|c|c|c|c|c|}
\hline \multirow[t]{3}{*}{ Pola Asuh Anak Autis } & \multicolumn{4}{|c|}{ Penanganan Anak Autis } & \multirow{2}{*}{\multicolumn{2}{|c|}{ Total }} & \multirow[t]{2}{*}{ Pvalue } \\
\hline & \multicolumn{2}{|c|}{ Kurang Baik } & \multicolumn{2}{|c|}{ Baik } & & & \\
\hline & $\mathbf{f}$ & $\%$ & $\mathbf{f}$ & $\%$ & $\mathbf{f}$ & $\%$ & \\
\hline Ortoriter & 1 & 100 & 0 & 0 & 1 & 100 & \\
\hline Permisif & 5 & 71.4 & 2 & 28.6 & 7 & 100 & \\
\hline Demokratis & 1 & 4.3 & 22 & 95.7 & 23 & 100 & 0,03 \\
\hline Total & 7 & 22.6 & 24 & 77.4 & 31 & 100 & \\
\hline
\end{tabular}

(Sumber : Data Primer, 2021)

Dari tabel 1. dapat diketahui bahwa dari 23 orang dengan Pola Asuh yang demokratis dominan baik dalam penanganan Anak Autis yaitu sebanyak 22 orang $(95.7 \%)$. Dan dari 8 orang pola asuh Permisif dan pola asuh Ortoriter kurang baik seluruh nya (100\% penanganan Anak Autis baik).

Selanjutnya uji statistic menunjukkan tabel tersebut tidak memenuhi syarat dengan uji Chi Square karena terdapat sel yang nilai expected nya kurang dari 5 ada $50.0 \%$ jumlah sel. Oleh karena itu, uji yang digunakan adalah uji alternatifnya, yaitu uji Kolmogorov - Smirnov diperoleh hasil nilai $p=0,003<0,05$, maka Ha diterima yang artinya terdapat hubungan pengaruh pola asuh terhadap penanganan anak autis di sekolah luar biasa Aneuk Nanggroe dan Cinta Mandiri di kota Lhokseumawe Provinsi Aceh.

\section{Pengaruh Pola Makan Terhadap Penanganan Anak Autis}

Dari hasil yang peneliti dapatkan mengenai Pola Makan Terhadap Penanganan Anak Autis Di SLB Aneuk Nanggroe Dan Cinta Mandiri Kota Lhoksemawe Provinsi Aceh adalah sebagai berikut: 
Tabel 2. Pengaruh Pola Makan Terhadap Penanganan Anak Autis Di Sekolah Luar Biasa Aneuk Nanggroe Dan Cinta Mandiri Kota Lhoksemawe Provinsi Aceh

\begin{tabular}{|c|c|c|c|c|c|c|c|}
\hline \multirow{3}{*}{$\begin{array}{l}\text { Pola Makan } \\
\text { Anak Autis }\end{array}$} & \multicolumn{4}{|c|}{ Penanganan Anak Autis } & \multirow{2}{*}{\multicolumn{2}{|c|}{ Total }} & \multirow[t]{3}{*}{ P-value } \\
\hline & \multicolumn{2}{|c|}{ Kurang Baik } & \multicolumn{2}{|c|}{ Baik } & & & \\
\hline & $\mathbf{f}$ & $\%$ & $\mathbf{F}$ & $\%$ & $\mathbf{F}$ & $\%$ & \\
\hline Kurang Sesuai & 7 & 33.3 & 14 & 66.7 & 1 & 100 & \\
\hline Sesuai & 0 & 0.0 & 10 & 100 & 7 & 100 & \\
\hline Total & 7 & 22.6 & 24 & 77.4 & 31 & 100 & \\
\hline
\end{tabular}

(Sumber : Data Primer, 2021)

Dari tabel 2 diatas dapat diketahui bahwa dari 21 orang dengan Pola Makan yang tidak sesuai dominan baik dalam penanganan Anak Autis yaitu sebanyak 14 orang $(66.7 \%)$. Dan dari 10 orang pola makan sesuai seluruh nya $(100 \%$ penanganan Anak Autis baik).

Selanjutnya uji statistic menunjukkan tabel tersebut tidak memenuhi syarat dengan uji Chi Square karena terdapat sel yang nilai expected nya kurang dari 5 ada $50.0 \%$ jumlah sel. Oleh karena itu, uji yang digunakan adalah uji alternatifnya, yaitu uji Fisher's Exact Test diperoleh hasil nilai $p=0,006>0,05$, maka H0 diterima yang artinya terdapat hubungan pengaruh pola makan terhadap penanganan anak autis di sekolah luar biasa Aneuk Nanggroe dan Cinta Mandiri di kota Lhoksemawe Provinsi Aceh.

\section{Pengaruh Terapi Social Stories Terhadap Penanganan Anak Autis}

Dari hasil yang peneliti dapatkan mengenai terapi social stories Terhadap Penanganan Anak Autis Di SLB Aneuk Nanggroe Dan Cinta Mandiri Kota Lhoksemawe Provinsi Aceh adalah sebagai berikut:

Tabel 3. Pengaruh Terapi Social Stories Terhadap Penanganan Anak Autis Di SekolahLuar Biasa Aneuk Nanggroe Dan Cinta Mandiri Kota Lhoksemawe Provinsi Aceh

\begin{tabular}{|c|c|c|c|c|c|c|c|}
\hline \multirow{3}{*}{$\begin{array}{l}\text { Terapi } \\
\text { Social } \\
\text { Stories }\end{array}$} & \multicolumn{4}{|c|}{ Penanganan Anak Autis } & \multirow{2}{*}{\multicolumn{2}{|c|}{ Total }} & \multirow[t]{3}{*}{ P-value } \\
\hline & \multicolumn{2}{|c|}{ Baik } & \multicolumn{2}{|c|}{ Kurang Baik } & & & \\
\hline & $\mathbf{f}$ & $\%$ & $\mathbf{f}$ & $\%$ & $\mathbf{f}$ & $\%$ & \\
\hline Baik & 19 & 90.5 & 2 & 9.5 & 21 & 100 & $0 \Omega$ \\
\hline $\begin{array}{l}\text { Kurang } \\
\text { Baik }\end{array}$ & 5 & 50 & 5 & 50 & 10 & 100 & \\
\hline Total & 24 & 77.4 & 7 & 22.6 & 31 & 100 & \\
\hline
\end{tabular}

(Sumber : Data Primer, 2021)

Dari tabel 3. diatas dapat diketahui bahwa dari 21 orang dengan terapi social stories baik dominan baik dalam penanganan Anak Autis yaitu sebanyak 19 orang $(90.5 \%)$. Dan dari 10 orang terapi social stories kurang baik 5 orang $(50 \%)$ penanganan Anak Autis baik.
Selanjutnya uji statistic menunjukkan tabel tersebut tidak memenuhi syarat dengan uji Chi Square karena terdapat sel yang nilai expected nya kurang dari 5 ada $50.0 \%$ jumlah sel. Oleh karena itu, uji yang digunakan adalah uji alternatifnya, yaitu uji Fisher's Exact Test diperoleh hasil nilai 
$p=0,022>0,05$, maka H0 diterima yang artinya terdapat pengaruh terapi social stories terhadap penanganan anak autis di sekolah luar biasa Aneuk Nanggroe dan Cinta Mandiri di kota Lhoksemawe Provinsi Aceh.

\section{PEMBAHASAN}

\section{Pengaruh Pola Asuh Terhadap Penanganan Anak Autis}

Hasil analisis dengan menggunakan uji chi-square pada level of significant $\alpha=0.05$ menunjukkan adanya hubungan pola asuh dengan penanganan anak autis $\boldsymbol{p}$-value 0.04 ) atau $\mathrm{p}<0,05$.

Pola asuh merupakan sikap orang tua dalam berinteraksi, membimbing, membina, dan mendidik anak dalam kehidupan seharihari agar menjadi anak yang sukses. Pengasuhan orangtua adalah memberikan tanggung jawab dan perhatian yaitu: kasih sayang dan hubungan dengan anak yang berlangsung, kebutuan materi seperti makan, pakaian dan tempat tinggal, disiplin, pendidikan intelektual dan moral, persiapan untuk bertanggung jawab sebagai orang dewasa atas tindakan anak kepada masyarakat luas. Pengasuhan dapat berarti suatu tindakan ataupun proses yang dinamis untuk merawat anak dengan baik (Mufadhilah, 2013).

Pola asuh disetiap keluarga selalu menghasilkan karakteristik yang berbeda pada setiap anak. Hal ini sesuai dengan penelitian Muryono (2011) yang menunjukkan bahwa pengasuhan orangtua yang otoriter dan pengasuhan orangtua yang permisif akan mendorong anak berperilaku agresif. Dengan demikian pola asuh dapat mempengaruhi kedekatan antara orang tua dan anak serta kemandirian anak dalam menitih masa tumbuh kembangnya (Lestari \&Sopingi, 2018).

Hasil penelitian yang telah dilakukan oleh Setyaningsih (2015) tentang gambaran pengetahuan orang tua terhadap pola asuh yang baik dan sikap positif terhadap keberadaan anak. Data yang mendukung tipe pola asuh orang tua adalah orang tua dengan tingkat pendidikan SMP 4\%, SMA 60\%, PT $36 \%$. Jika dilihat dari usia responden maka $72 \% \geq 35$ tahun, 24\% usia 20-35 tahun dan 4\%, 20 tahun. Presetya (2011) menyatakan bahwa orang tua yang memiliki pendidikan yang baik maka cenderung akan menetapkan pola asuh yang lebih demokratis ataupun permisif dibandingkan dengan orang tua yang pendidikannya terbatas. Sedangkan menurut Supartini (2010) bahwa rentang usia tertentu adalah baik untuk menjalankan peran pengasuhan. Apabila terlalu muda atau terlalu tua, mungkin tidak dapat menjalankan peran tersebut secara optimal karena diperlukan kekuatan fisik dan psikososial.

Menurut asumsi peneliti, pola asuh orang tua terhadap anak sangat berpengaruh pada tingkat pendidikan orang tua, karena jika tingkat pendidikan tinggi maka tingkat pengetahuan orang tua lebih luas, oleh sebab itu pola asuh yang diterapkan kepada anak maka lebih dominan pola asuh Demokratis, apalagi pola asuh orang tua yang diterapkan pada anak dengan kelainan Autis.

Pola asuh orang tua dengan tiga jenis pola pengasuhan dapat mempengaruhi penanganan anak autis. Dengan pola asuh yang baik akan menciptakan kemandirian yang tinggi, sehingga dapat diartikan pola asuh mampu menciptakan hubungan yang selaras, serasi dan seimbang apabila diterapkan dengan bijak dan baik, guna meningkatkan penanganan anak autis. Dengan demikian dapat dipahami apabila pola asuh anak terpenuhi dengan baik dalam kehidupan sehari-hari antara orang tua dan anak maka penanganan pada anak akan meningkat.

\section{Pengaruh Pola Makan Terhadap Penanganan Anak Autis}

Dari tabel diatas dapat diketahui bahwa dari 21 orang dengan Pola Makan yang tidak sesuai dominan baik dalam penanganan Anak Autis yaitu sebanyak (66.7\%). Dan dari 10 orang pola makan sesuai seluruh nya (100\% penanganan Anak Autis baik). 
Hasil analisis dengan menggunakan uji chi-square pada level of significant $\alpha=0.05$ menunjukkan adanya hubungan pola makan dengan penanganan anak autis ( $\boldsymbol{p}$-value 0.006 ) atau $\mathrm{p}>0,05$.

Pola makan adalah suatu cara atau usaha dalam pengaturan jumlah dan jenis makanan dengan maksut tertentu, seperti mempertahankan kesehatan, status nutrisi, mencegah atau membantu kesembuhan penyakit. Pola makan sehari-hari merupakan pola makan seseorang yang berhubungan dengan kebiasaan makan sehari-hari (Adriani \&Wijatmadi, 2012). Pola makan adalah suatu cara atau usaha dalam pengaturan jumlah dan jenis makanan dengan informasi gambaran dengan meliputi mempertahankan kesehatan, status nutrisi, mencegah atau membantu kesembuhan penyakit (Depkes RI, 2009).

Pasien autis harus melakukan diet, banyak penelitian yang mebuktikan bahwa gangguan saluran pencernaan yang disebut leaky gut (kebocoran saluran cerna) terjadi pada sebagian besar pasien autis dan sangat berpengaruh pada gangguan fungsi otak yang mengakibatkan gangguan perilaku (Berding \& Donovan, 2016).

Intervensi diet diperlukan untuk mengatahui gejala autitik yang timbul pada autisme, misalnya pengaruh makanan terhadap sensitivitas usus, penyakit radang usus, candida, dan infeksi virus. Frekuensi gangguan saluran pencernaan dan alergi makanan pada anak autisme relative tinggi, dan efek terapi diet ini berbeda untuk setiap anak autis oleh karena itu disarankan untuk konsultasi denga Dokter ahli penyakit metabolik sebelum mengikuti pola diet (Roedi Irawan, 2019).

Hasil penelitian yang telah dilakukan oleh Sofia (2012) di Bandung, didapatkan bahwa sebanyak $85 \%$ orang tua yang tidak patuh dalam menerapkan diet GFCF berdampak pada terjadinya gangguan perilaku anak mereka dibandingkan pada anak autis yang orang tuanya patuh menjalankan diet. Hal tersebut terjadi karena tidak semua makanan yang mengandung gluten dan kasein dapat dengan mudah dihilangkan dari menu makanan anak. Ketidakpatuhan tersebut akan menyebabkan gangguan perilaku anak autis seperti mengamuk. Anak autis yang menjalani diet GFCF secara patuh memiliki emosi yang lebih stabil dan lebih tenang.

Ketidak patuhan orang tua terhadap diet dipengaruhi oleh salah satunya faktor pengetahuan. Hal ini sesuai dengan hasil penelitian yang telah dilakukan oleh Qamariah (2018) tentang gambaran pengetahuan ibu terhadap pola makan dan status gizi anak autis, didapatkan hasil bahwa mayoritas pendidikan ibu SMA yaitu 23 orang $(63.9 \%)$ dan minoritas pendidikan ibu SD-SMP sebanyak 5 orang (13.9\%).

Menurut asumsi peneliti bahwasanya diet pada anak autis sangat dibutuhkan dikarenakan jika anak autis tidak melakukan diet casein dan gluten maka dapat menganggu saluran pencernaan, sangat berpengaruh pada gangguan fungsi otak yang mengakibatkan gangguan perilaku. Pola makan pada anak terutama anak autis harus mengandung jumlah zat gizi, terutama karbohidrat, protein dan kalsium yang tinggi guna memenuhi kebutuhan selama masa pertumbuhan dan perkembangan.

Pengetahuan ibu terhadap tingkat pendidikan juga sangat mempenagruhi pola makan pada anak autis. Berdasarkan yang telah peneliti lakukan di SLB Aneuk Nanggroe dan Cinta Mandiri bahwasanya ibu yang pendidikan nya tinggi maka lebih menerapkan pola diet pada anak nya dengan mengatur pola makan, dan hanya memberikan makanan yang boleh dikonsumsi oleh anaknya.

\section{Pengaruh Terapi Social Stories Terhadap Penanganan Anak Autis}

Dari tabel diatas dapat diketahui bahwa dari 21 orang dengan terapi social stories baik dominan baik dalam penanganan Anak Autis yaitu sebanyak 19 orang (90.5\%). Dan dari 10 orang terapi social stories kurang baik 5 orang $(50 \%)$ penanganan Anak Autis baik. 
Hasil analisis dengan menggunakan uji chi-square pada level of significant $\alpha=0.05$ menunjukkan adanya pengaruh terapi social stories terhadap penanganan anak autis di sekolah luar biasa Aneuk Nanggroe dan Cinta Mandiri di kota Lhoksemawe Provinsi Aceh ( $\boldsymbol{p}$-value 0.022) atau p $>0,05$.

Konsep metode siswa berbasis social story memberikan gambaran pada individu mengenai petunjuk sosial yang relevan dan respon yang diharapkan dalam suatu situasi tertentu. Social story adalah cerita naratif pendek (20-150 kata) yang menggambarkan karakteristik spesifik dari suatu situasi, konsep dari keterampilan sosial yang dibutuhkan individu (Novita Siswati, 2010).

Deteksi dini anak dengan ADHD atau Gangguan Pemusatan Perhatian dan Hyperaktif Pada Anak Usia Sekolah (GPPH) di SD pada Kecamatan Lhoksukon dominan berada pada kategori tidak hiperaktif menggambarkan bahwa prevalensi hiperaktif tidak terlalu tinggi, namun perlu terus diwaspadai guna mendeteksi seluuruh anak dengan resiko GPPH untuk penanganan lebih lanjut (Eka Sutrisna \& Mailindawati, 2019).

Metode Social story dapat mengatasi defisit kognitif dan perilaku termasuk interaksi sosial yang dialami anak dengan ADHD melalui pemberian informasi dan petunjuk sosial yang mudah dipahami anak (Novita Siswati, 2010).

Hasil penelitian ini sesuai dengan penelitian yang dilakukan oleh Retno Twistiandayani dan Khoiroh Umah tahun 2016 tentang analisis faktor-faktor yang mempengaruhi interaksi sosial pada anak autis di Resource Center Kabupaten Gresik. Hasil penelitian ini menunjukkan bahwa pada kelompok perlakuan yang diberikan terapi wicara didapatkan hasil bahwa tidak ada pengaruh faktor umur $(\rho=0,428)$, jenis kelamin $(\rho=1,000)$, lingkungan $(\rho=1,000)$ dan sosial budaya $(\rho=1,000)$ dengan interaksi sosial anak autis. Pada kelompok kontrol yang dilakukan terapi social stories ada pengaruh faktor umur $(\rho=0,018)$ dan tidak ada pengaruh factor, jenis kelamin $(\rho=1,000)$, lingkungan $(\rho=1,000)$, sosial budaya $(\rho=1,000)$ dengan interaksi sosial anak autis.

Metode pembelajaran melalui social story diharapkan dapat mengatasi interaksi sosial dan perilaku yang dialami anak dengan autis melalui pemberian informasi dan petunjuk sosial yang relevan. Informasi mengenai petunjuk sosial diberikan lewat kalimat deskriptif (penggambaran situasi sosial), kalimat perspektif (penggambaran keadaan internal yang dialami karakter cerita), dan kalimat direktif (penjelasan mengenai jenis-jenis respon yang sesuai). Social story memberikan gambaran pada anak autis mengenai petunjuk sosial yang relevan dan respon yang diharapkan dalam suatu situasi tertentu. Social story memberikan informasi sosial secara nyata dan jelas yang tidak dipahami atau terlewatkan oleh individu. Informasi yang disampaikan melalui social story dapat memperjelas keseluruhan gambaran mengenai situasi sosial.

Menurut asumsi peneliti bahwasanya terapi social stories pada anak autis sangat dibutuhkan dikarenakan jika anak autis tidak melakukan berinteraksi sosial, maka dapat meningkatkan keterampilan sosial yang dibutuhkan anak, sehingga dapat mengatasi kekurangan kemampuan kognitif. Interaksi sosial yang dialami anak autis melalui pemberian informasi dan petunjuk sosial yang mudah dipahami oleh anak dan dapat menjadi salah satu alternatif terapi dalam penanganan anak autis.

\section{KESIMPULAN}

Dari hasil penelitian yang berjudul "Analisa Faktor-Faktor yang Mempengaruhi Penanganan Anak Autis Di Sekolah Luar Biasa Aneuk Nanggroe Dan Cinta Mandiri Kota Lhoksemawe Provinsi Aceh" didapatkan bahwa : ada pengaruh pola asuh terhadap penanganan anak autis menunjukkan adanya hubungan ( $\boldsymbol{p}$-value 0.04 ) atau $\alpha<0,05$, tidak ada pengaruh pola makan terhadap penanganan anak autis menunjukkan bahwa tidak adanya pengaruh 
dengan nilai $\boldsymbol{p}$-value $<\alpha(0.06>0.05)$ dan ada pengaruh terapi social stories terhadap penanganan anak autis menunjukkan bahwa tidak adanya pengaruh dengan nilai $\boldsymbol{p}$-value $<\alpha(0.02<0.05)$.

Adapun saran dalam penelitian ini antara lain bagi responden dapat lebih mengetahui cara dalam mengasuh dan memberikan pola makan yang baik terhadap anak dengan kelainan autisme serta melakukan terapi social stories sebagai upaya penanganan anak autis.

\section{UCAPAN TERIMAKASIH}

Ucapan terimakasih dalam penelitian ini untuk responden penelitian (orang tua anak autis) yang telah bersedia menjadi sampel dalam penelitian ini serta bersedia meluangkan waktunya pada saat observasi dan penyebaran kuisioner dan Kepala Sekolah Luar Biasa Aneuk Nanggroe Dan Cinta Mandiri Kota Lhoksemawe Provinsi Aceh, yang telah memberikan ijin penelitian.

\section{DAFTAR PUSTAKA}

Adams. (2013). Center For Disease (CDC), Jakarta: PT elex media komputindo.

Adriani, Wijatmadi. (2012). Pengantar Gizi Masyarakat. Jakarta : Kencana.

Berding \& Donovan. ( 2016). Mengenali Dan Memahami Tunbuh Kembang Anak. Yogyakarta : Katahati.

Budiyanto. (2018). Merancang identifikasi, asesmen, planning matriks dan layanan kekhususan peserta didik berkebutuhan khusus disekolah inklusif. Surabaya : CV. Jakad Publising.

Data SLB Aneuk Nanggroe Dan SLB Cinta Mandiri (2020). Data Anak Autis. Kabupaten : Aceh Utara.

Depkes RI. (2009). Pengertian pola makan pada anak dalam menjaga ststus gizi anak.

Eka Sutrisna \& Mailindawati. (2019). Deteksi Dini Gangguan Pemusatan
Perhatian dan Hyperaktif (GPPH) Pada Anak Usia Sekolah Dasar di Kecamatan Lhoksukon Kabupaten Aceh Utara. Terdapat pada : https://ejournal.bbg.ac.id/care/article/ view/1448.

Fatmawati, Rauf SP. (2014). Faktor Yang Mempengaruhi Kecemasan Orang Tua Terhadap Perkembangan Anak Autis Disekolah Luar Biasa. Journal Pengaruh Pola Pengasuhan Dengan Perkembangan Komunikasi Anak Autis Kepada Orang Tua November 2015 Volume 4 Nomor 8. Lampung :

Fakultas Kedokteran, Universitas Lampung.

Gunadi. (2011). Mereka Pun Bisa Sukses. Jakarta : Penebar Plus.

Lestari \& Sopingi. (2018). Hubungan Pola Asuh Orangtua Dan Kemandirian Anak Autis, Universitas Negeri Malang.

Lyte \& Cryan. (2014). Gangguan Metabolic Otak \& Terapi Nutrisi Pada Anak Autisme. Jawa Timur: Airlangga University Press.

Mohammadi M. (2014). Family function, Parenting Style and Broader Autism Phenotype as Predicting Factors of Psychological Adjustment in Typically Developing Siblings of Children with Autism Spectrum Disorders. Iran J Psychiatry. 2014: 2(15):55-63.

Mufadilah (2013). Studi Pengasuhan Orangtua Pada Anak Autis, Fakultas Kedokteran : Universitas Lampung.

Muryono (2011). Empati, Penalaran Moral Dan Pola Asuh. Yogyakarta: Gala Ilmu Semesta.

Novita Siswati. (2010). Pengaruh sosial stories tehadap keterampilan sosial anak dengan ADHD. Jurnal. Jurnal psikologi Undip: Semarang.

Presetya (2011). Autisme Pemahaman Baru Untuk Hidup Bermakna Bagi Orangtua. Yogyakarta: Penerbit Graha Ilmu. 
Qamariah, N. (2018). Gambaran Pengetahuan Ibu Terhadap Pola Makan Dan Status Gizi Anak Autis Di Yayasan Pembinaan Anak Cacat (YPAC) Banda Aceh.

Retno Twistiandayani dan Khoiroh Umah. (2016). Analisis Faktor-Faktor Yang Mempengaruhi Interaksi Sosial Pada Anak Autis Di Resource Center Kabupaten Gresik. Terdapat Pada: http://proceeding.unisba.ac.id/index.p hp/kesehatan/article/view/993.

Riandini. (2015). Panduan Autisme Terlengkap. Jakarta: Dian Rakyat.

Roedi Irawan (2019). Gangguan metabolik otak \& terapi nutrisi pada Anak autis.
Airlangga university press.

Setyaningsih. (2015). Hubungan Pola Asuh Orang Tua Dengan Perkembangan Sosial Anak Autisme Di SLB Harmoni Sukarata. Jurnal Kesehatan, Politeknik Kesehatan Sukarata.

Sofia (2012). Hubungan Pengetahuan Dan Sikap Ibu Tentang Gizi Terhadap Status Gizi Pada Anak Autisme. Fakultas Keperawatan: Universitas Riau.

Supartini (2010). Perkembangan Anak. Jakarta: EGC.

WHO (2013). Profil Data Anak Autisme Diseluruh Dunia.Terdapat Pada : sehatnegriku.kemenkes.go.id. 